\title{
Academic Supervision of School Principals, Principal Transformational Leadership, and School Climate on Senior High School Teachers' Competence
}

\author{
Longginus Laga Belan', M.D Niron ${ }^{2}$ \\ DOI: 10.35445/alishlah.v13i3.825
}

Info Artikel

Keywords:

Principal academic

supervision;

Principal

transformational

leadership;

School climate and pedagogic;

Professional competence

Kata kunci: Supervisi akademik

kepala sekolah;

Kepemimpinan transformasional;

Iklim sekolah dan

kompetensi;

Pedagogik dan

profesional

\section{Abstract}

The study aims to determine and describe the effect of principal academic supervision, principal transformational leadership, and school climate toward pedagogic and professional competence of teachers in Senior High School in Lembata Regency. The research uses a quantitative approach with the ex-post facto type. The population was 200 teachers of Senior High School who taught national exam subjects in Lembata Regency. The sample was 127 teachers using the simple random sampling technique. Data collection used is questionnaires with expert validation and empirical tests. Multiple regressions are used to analyze the data. Based on the study results, it was found that the principal's academic supervision affected teacher competence. The principal's transformational leadership also affected teacher competence, and the school climate affected teacher competence. So that the principal's academic supervision, principal's transformational leadership, and school climate on teacher competence in Lembata.

\begin{abstract}
Abstrak
Penelitian ini bertujuan untuk mengetahui dan mendeskripsikan pengaruh supervisi akademik kepala sekolah, kepemimpinan transformasional kepala sekolah, dan iklim sekolah terhadap kompetensi pedagogik dan profesional guru di SMA Negeri di Kabupaten Lembata. Penelitian ini menggunakan pendekatan kuantitatif dengan tipe ex-post facto. Populasi penelitian ini adalah 200 guru SMA yang mengajar mata pelajaran ujian nasional di Kabupaten Lembata. Sampel penelitian adalah 127 guru dengan teknik simple random sampling. Pengumpulan data yang digunakan adalah angket dengan validasi ahli dan uji empiris. Regresi berganda digunakan untuk menganalisis data. Berdasarkan hasil penelitian ditemukan pengaruh supervisi akademik kepala sekolah terhadap kompetensi guru. Kepemimpinan transformasional kepala sekolah juga mempengaruhi kompetensi guru, selain itu iklim sekolah mempengaruhi kompetensi guru. Sehingga supervisi akademik kepala sekolah, kepemimpinan transformasional kepala sekolah, dan iklim sekolah terhadap kompetensi guru di Lembata.
\end{abstract}

\footnotetext{
${ }^{1}$ Universitas Negeri Yogyakarta, Yogyakarta, Indonesia

Email: longginuslaga.2019@student.uny.ac.id

${ }^{2}$ Universitas Negeri Yogyakarta, Yogyakarta, Indonesia

Email: niron@uny.ac.id
}

Vol.13 (3) December 2021

Received: July 19, 2021; Received in revised form: July 27, 2021; Accepted: September 27, 2021; Available online: December 13, 2021. This is an open-access article under a Creative Commons Attribution-NonCommercial-ShareAlike 4.0 International License 
Longginus Laga Belan, M.D Niron

\section{INTRODUCTION}

Education is a vehicle to improve human resources in Indonesia. It is hoped that through education, students will develop all abilities, piety and intelligence, skills, independence and other abilities (Abidin, 2019). To provide education that meets the above criteria, it is necessary to prepare human resources, especially in the educational process (Grochalska, 2020). Among the factors that determine success in education, the main factor and leader in improving the quality of education is the teacher (Sebastian \& Allensworth, 2012). Teachers take a very strategic position in preparing the nation's future through their success in equipping their students with appropriate knowledge, shaping the character of children who have a noble character, have high teaching ethics and are ready to compete with other countries in the world (Maryanti et al., 2020; Orchard \& Winch, 2015).

Improving the quality of education is still becoming up-to-date discussed today. The Indonesian government has made many breakthroughs, but they do not appear to have produced satisfactory results (Fitriatun, 2020). The quality of education in Indonesia is still low. As stated by the general chairman of the PGRI board, Unifah Rosyidi, the quality of education in Indonesia has not been proud when viewed from the global/international education quality indicators. When viewed based on quantitative statistics, the quality of education has remarkable achievement in access to education opportunities (Ronfeldt et al., 2015). One indicator to measure the quality of education in Indonesia is to use the Program for International Student Assessment (PISA) evaluation scores (Argina et al., 2017; Oktiningrum et al., 2016). The PISA report released on December 3, 2019, shows that the 2018 PISA score for Indonesia's reading literacy ability is ranked 72 out of 77 countries, mathematics score is ranked 72 out of 78 participating countries, while science score is ranked 70 out of 78 countries (Aditomo \& Faridz, 2019).

Indonesia's reading literacy ability is only able to reach a score of 371, it still far from the average reading ability score of countries members of The Organization for Economic Cooperation and Development (OECD), which is 487 (Del Zulia Venezuela et al., 2020; Latifah \& Amelia, 2019). If it is examined from the gotten score, the literacy ability of Indonesians has decreased since becoming a PISA participant in 2000. Other data from UNESCO accessed from the Global Education Monitoring (GEM) Report shows that the education of Indonesia occupies the 1oth position out of 14 developing countries and teachers as an essential factor in determining the educational development of students are in the order of 14 of the 14 developing countries studied (Nag et al., 2014).

It illustrates how the teacher is an essential component of the educational microsystem and plays a large role in the wider educational process. Given the very important role of teachers, teachers should carry out their duties and responsibilities as educators professionally and not carelessly (Sileo, 2011). Teachers must demonstrate their work as full of dedication based on certain knowledge or skills (King, 2014). In carrying out their duties in education, teachers are required to demonstrate their ability as qualified and professional educators (Alexander et al., 2019; Sachs, 2016). It happens because teachers are professional educators with the main task of educating, teaching, guiding, directing, training, assessing, and evaluating students in early childhood education through formal education, basic education, and secondary education, as stated in Government Regulation no. 19 Year 2017 concerning teachers and lecturers. Professional teacher quality is supported by at least four basic competencies: pedagogic competence, social competence, and personality competence. This is by the mandate in Law No. 14 the Year 2005 concerning Teachers and Lecturers article (10) paragraph (1) (Law of the Republic of Indonesia No. 14 of 2005 regarding Teachers and Lecturers, 2005). Teachers' ability will be one of the determinants of academic success (Mkumbo \& Amani, 2012; Mohzan et al., 2013). With their abilities, teachers can influence students to study seriously and influence students to develop their potential. Children have independent attitudes, social attitudes, and academic abilities needed to develop further their knowledge (Bardach \& Klassen, 2020; Kraft, 2019). One factor that supports the development of a teacher's skills is support from superiors, in this case, the principal. The principal is 
the highest leader in a school. Therefore every decision and policy taken by the principal will succeed in the school organization. This is called transformational leadership.

Principal transformational leadership changes school organizations (Anderson, 2017a; Hsiao \& Chang, 2011). A principal in carrying out his duties and functions can maximally transform what he has to his subordinates (teachers and education staff) and can also use all the resources owned by all school components to achieve school organizational goals (Andriani et al., 2018; Balyer, 2012; Li \& Liu, 2020). Transformational leadership stems from the belief that charismatic leaders are as desired by their followers that leaders will always retain followers because leaders have big souls (Anderson, 2017b; Bass, 1995; Rofiq, 2019). In theory, it can be said that transformational leadership is a leadership style that inspires subordinates, involves them, and has a shared commitment to realizing the organization's vision (Balyer, 2012).

Academic supervision is centred on student learning problems. The principal carries out this supervision to determine the teaching ability of teachers, who will then be given guidance so that the point of supervision is not to assess teacher performance but to provide guidance for teachers (KhunInkeeree et al., 2019; Maritasari et al., 2020; Poernamawijaya et al., 2018). Usually, the supervision carried out by the principal is carried out by visiting classes, group discussions, individual coaching, and learning simulations (Altun \& Yengin Sarkaya, 2020). Principal's academic supervision is an activity to assist teachers in the learning process, which consists of planning, implementing, and evaluating learning to achieve the planned goals (Renata et al., 2018). The principal's academic supervision is also in order to provide services and assistance to teachers to improve competence in carrying out their duties as professional educators (Wagner, 2020). Academic supervision is not intended to find teachers' mistakes, but it aims to improve and motivate teachers to improve their competence in carrying out their duties and responsibilities (Supriyono et al., 2017). According to Glickman, Gordon, \& Ross-Gordon, (2017), the objectives of academic supervision can be grouped into three components, namely; 1) growing teacher motivation, 2) developing teacher professionalism, and 3) supervising the quality of teacher teaching. Transformational leadership also supports the existence of academic supervision by the principal.

Principal transformational leadership is closely related to leaders who want a change (Day et al., 2016). The principal acts as a change agent with the main function as a change catalyst, not as a charge controller (Şahin et al., 2017). The Principal's transformational leadership focuses on achieving the school's vision by encouraging and inspiring teachers to achieve school goals (Anderson, 2017b). The essence of transformational leadership is to empower followers to perform effectively by building their commitment to new values, developing followers' skills and beliefs, and creating a climate conducive to the development of innovation and creativity (Mora, 2012). It needs to be supported by the school climate.

School climate is an atmosphere that occurs in the school environment which is strongly influenced by the components of the leadership and management of the principal and the way teachers, education staff, and students are treated as well as the level and quality of relationships between elements in school administration (Damayanti, 2017; Thapa et al., 2013). School climate is a part that is strongly influenced by the components of the principal's leadership and the way teachers are treated as well as the level and quality of relationships between elements in school administration (Capp et al., 2020; Rudasill et al., 2018). Meanwhile, it is necessary to have a teacher's competence to fulfil this. Competence is a collection of knowledge, behaviour, and skills that teachers must possess to achieve learning and educational goals. Competence is obtained through education, training, and independent learning by utilizing learning resources (Selvi, 2010). There are four dimensions of teacher competence in Indonesia: pedagogic

Based on previous research conducted by (2020), there is an effect between professional and educational competency of teachers toward principle academic supervision. Then, Narung (2020) 


\section{Longginus Laga Belan , M.D Niron}

states that the principal's transformational leadership affects teachers' pedagogic and professional competencies. On the other hand, Nuraini (2016) states no relationship between school climate and teacher pedagogic and professional competence. From previous studies, researchers are interested in combining several variables such as academic supervision by school principals, principal transformational leadership, school climate on high school teacher competence.

Based on the background of the problem, the researcher is interested in researching the effect of the principal's academic supervision, the principal's transformational leadership, and school climate toward the pedagogic and professional competence of teachers who are teaching national exam subjects. 200 national exam subject teachers are spread across 11 (eleven) public and private high schools. Therefore, this study will be limited to only three variables that affect teachers' pedagogical and professional competence: the school principal's academic supervision variable, the principal's transformational leadership, and school climate at Senior High Schools in Lembata.

\section{METHODS}

The approach used in this research is quantitative research. This research is ex-post-facto research, which is a study that aims to find the causes that allow changes in behaviour, symptoms, or phenomena caused by an event, behaviour, or things that cause changes in the independent variables generally occurred. This research will be conducted at a high school in Lembata, East Nusa Tenggara Province, with the time of the study occurring from March to April 2021.

The population in this study was several teachers of the National Examination (UN) subjects in eleven high schools in the Lembata Regency. Based on data obtained from each high school principal, 200 teachers from eleven senior high schools in Lembata Regency are teaching the National Examination subject. A simple random sampling technique was used in the sampling of this study because sample members from the population were taken randomly without regard to the strata in the population.

The data analysis technique uses SPSS program. The technique of collecting data was using a questionnaire, in which the questionnaire was compiled based on a grid of instruments from the indicators of variables of the principal's academic supervision, the principal's transformational leadership, the school climate, and the pedagogic and professional competencies of the national exam subject teachers.

\section{FINDINGS AND DISCUSSIONS}

\section{Normality Test}

The normality test in this study determines whether the four research variables are normally distributed or not.

Table 1. Result of Kolmogorov-Smirnov Test

\begin{tabular}{|c|c|c|c|c|c|}
\hline & & $\begin{array}{c}\text { Principle } \\
\text { Academic } \\
\text { Supervision } \\
\text { (X1) }\end{array}$ & $\begin{array}{l}\text { Transformational } \\
\text { Leadership } \\
\text { (X2) }\end{array}$ & $\begin{array}{l}\text { School } \\
\text { Climate } \\
\text { (X3) }\end{array}$ & $\begin{array}{c}\text { Teacher } \\
\text { Competency } \\
\text { (Y) }\end{array}$ \\
\hline \multicolumn{2}{|l|}{$\mathrm{N}$} & 127 & 127 & 127 & 127 \\
\hline \multirow{2}{*}{$\begin{array}{l}\text { Normal } \\
\text { Parameters }{ }^{a, b}\end{array}$} & Mean & 101,1732 & 71,5433 & 109,4409 & 107,5276 \\
\hline & $\begin{array}{l}\text { Std. } \\
\text { Deviation }\end{array}$ & 14,36767 & 11,91954 & 17,82216 & 16,97376 \\
\hline \multirow{3}{*}{$\begin{array}{l}\text { Most } \\
\text { Extreme } \\
\text { Differences }\end{array}$} & Absolute & ,061 & ,045 & ,060 & ,072 \\
\hline & Positive & ,054 & ,028 & ,060 & ,039 \\
\hline & Negative &,- 061 &,- 045 &,- 046 &,- 072 \\
\hline \multicolumn{2}{|l|}{ Test Statistic } & ,061 & , 045 & ,060 & ,072 \\
\hline \multicolumn{2}{|c|}{ Asymp. Sig. (2-tailed) } & $.200^{\mathrm{c}, \mathrm{d}}$ & $.200^{\mathrm{c}, \mathrm{d}}$ & $.200^{\mathrm{c}, \mathrm{d}}$ & $.182^{\mathrm{c}}$ \\
\hline
\end{tabular}




\begin{tabular}{l}
\hline a. Test distribution is Normal. \\
\hline b. Calculated from data. \\
\hline c. Lilliefors Significance Correction. \\
\hline d. This is a lower bound of the true significance.
\end{tabular}

Table 2. Result of Normality test conclusion table

\begin{tabular}{lrc}
\hline Variable & Sig & Information \\
\hline Principle Academic Supervision & 0,200 & Normal \\
\hline Principle Transformational Leadership & 0,200 & Normal \\
\hline School Climate & 0,200 & Normal \\
\hline Teacher Competence & 0,182 & Normal \\
\hline
\end{tabular}

Source: Primary Data of 2021

After the normality test, all existing research variables showed that the significance value was greater than 0.05. Therefore it can be concluded that all research variables were normally distributed.

\section{Linearity Test}

Linearity testing is carried out to determine whether there is a linear relationship between the independent and dependent variables.

Table. 3 Linearity Test Conclusion Table

\begin{tabular}{lll}
\hline Variable & Sig & Information \\
\hline Principle Academic Supervision & 0,200 & Normal \\
\hline Principle Transformational Leadership & 0,200 & Normal \\
\hline School Climate & 0,200 & Normal \\
\hline
\end{tabular}

Source: Primary Data of 2021

From the table above, it can be seen that the linearity test for all variables shows the value of sig. deviation from linearity is greater than 0.05, so it can be concluded that the relationship between all research variables is linear.

\section{Multicollinearity Test}

The purpose of the multicollinearity test is to find out how big the inter-correlation value is between the three independent variables or the inter-correlation value between $\mathrm{X}_{1}, \mathrm{X}_{2}$ and $\mathrm{X}_{3}$. It is said that there is a multicollinearity relationship between the three independent variables if there is a correlation between the three independent variables.

Table. 4 Multicollinearity Test Table

\begin{tabular}{lccc}
\hline \multicolumn{1}{c}{ Variable } & Tolerance & VIP & Information \\
\hline Principle Academic Supervision & 0,191 & 5,234 & $\begin{array}{c}\text { There is no } \\
\text { multicollinearity }\end{array}$ \\
\hline Principle Transformational Leadership & 0,380 & 2,628 & $\begin{array}{c}\text { There is no } \\
\text { multicollinearity }\end{array}$ \\
\hline School Climate & 0,339 & 2,866 & $\begin{array}{c}\text { There is no } \\
\text { multicollinearity }\end{array}$ \\
\hline
\end{tabular}

Source: Primary Data of 2021

Based on the table above, it is known that the three independent variables have a tolerance value greater than 0.1 and a VIP value less than 10. Therefore it is concluded that the regression model in this study does not occur multicollinearity. 


\section{Heteroscedasticity Test}

The heteroscedasticity test serves to test the symptoms of inequality of variance of the residual value from one observation to another observation.

Table. 5 Heteroscedasticity test table

\begin{tabular}{|c|c|c|c|c|c|c|}
\hline \multicolumn{7}{|c|}{ Coefficients } \\
\hline \multirow{2}{*}{\multicolumn{2}{|c|}{ Model }} & \multicolumn{2}{|c|}{$\begin{array}{l}\text { Unstandardized } \\
\text { Coefficients }\end{array}$} & \multirow{2}{*}{$\begin{array}{c}\text { Standardized } \\
\text { Coefficients }\end{array}$} & \multirow[t]{2}{*}{$\mathrm{t}$} & \multirow[t]{2}{*}{ Sig. } \\
\hline & & B & $\begin{array}{l}\text { Std. } \\
\text { Error }\end{array}$ & & & \\
\hline \multirow[t]{4}{*}{$\mathbf{1}$} & (Constant) & 14,335 & 3,370 & & 4,254 & ,000 \\
\hline & $\begin{array}{l}\text { Principle Academic Supervision } \\
\text { (X1) }\end{array}$ &,- 088 & , O74 &,- 242 & $-1,196$ & ,234 \\
\hline & Transformational Leadership (X2) &,- 010 & ,063 &,- 023 &,- 164 & ,870 \\
\hline & School Climate (X3) & ,029 & ,044 & ,098 & 652 & ,516 \\
\hline
\end{tabular}

a. Dependent Variable: Abs_res

The table of heteroscedasticity test results shows that the significance value for the principal's academic supervision variable is 0.234 ; the significance value of the principal's transformational leadership variable is 0.870 ; and the significance value for the school climate variable is 0.516 . The significance value of the three variables shows a value greater than 0.05. Based on the decision-making guidelines, it can be concluded that there is no symptom of heteroscedasticity in the regression model equation so that it can meet the requirements of the linear regression test.

\section{Hypothesis Testing}

The purpose of hypothesis testing is to prove the effect of principal's academic supervision, transformational leadership, and school organizational climate on teachers' pedagogic and professional competence in Lembata Regency - East Nusa Tenggara.

Table 6. Hypothesis testing table

\section{Coefficients}

\begin{tabular}{|c|c|c|c|c|c|c|}
\hline \multicolumn{2}{|c|}{ Model } & \multicolumn{2}{|c|}{$\begin{array}{l}\text { Unstandardized } \\
\text { Coefficients }\end{array}$} & \multirow{2}{*}{$\begin{array}{c}\text { Standardized } \\
\text { Coefficients } \\
\text { Beta }\end{array}$} & \multirow[t]{2}{*}{$\mathrm{t}$} & \multirow[t]{2}{*}{ Sig. } \\
\hline & & B & $\begin{array}{l}\text { Std. } \\
\text { Error }\end{array}$ & & & \\
\hline \multirow[t]{4}{*}{1} & (Constant) & 6,049 & 6,189 & & ,977 & ,330 \\
\hline & $\begin{array}{l}\text { Principle Academic } \\
\text { Supervision (X1) }\end{array}$ & ,533 & ,135 & ,451 & 3,937 & , OOO \\
\hline & $\begin{array}{l}\text { Transformational Leadership } \\
\text { (X2) }\end{array}$ & ,408 & ,116 & ,286 & 3,524 & ,001 \\
\hline & School Climate $\left(\mathrm{X}_{3}\right)$ & , 168 & , o81 & ,176 & $\begin{array}{r}2,07 \\
9\end{array}$ & ,040 \\
\hline
\end{tabular}

a. Dependent Variable: Teacher Competency (Y)

\begin{tabular}{lllll}
\hline \multicolumn{1}{c}{ Variable } & \multicolumn{1}{c}{$\begin{array}{c}\text { Regression } \\
\text { Coefficient (b) }\end{array}$} & t-count & Sig. & Conclusion \\
\hline Principle Academic Supervision & 0,451 & 3,937 & 0,000 & Signifikan \\
\hline $\begin{array}{l}\text { Principle Transformational } \\
\text { Leadership }\end{array}$ & 0,286 & 3,524 & 0,001 & Signifikan \\
\hline School Climate & 0,176 & 2,079 & 0,040 & Signifikan \\
\hline Constant $=6,049$ & & & & \\
\hline $\mathrm{R}^{2}=0,684$ & & & & \\
\hline F-count $=91,810$ & & & & \\
\hline Sig. $=0,000$ & & & & \\
\hline
\end{tabular}


The multiple regression equation from the results of the regression analysis can be seen as follow: $\mathrm{Y}=6,049+0,451 \mathrm{X} 1+0,286 \mathrm{X} 2+0,176 \mathrm{X}_{3}+\mathrm{e}$.

\section{Determination Coefficient $\left(\mathbf{R}^{2}\right)$}

To measure the percentage of the influence of the independent variable on the dependent variable, a coefficient of determination is needed as a measuring tool. The coefficient of determination or $\mathrm{R}$ Square / $\mathrm{R}$ Square is useful for predicting and seeing how much the variables $\mathrm{X} 1, \mathrm{X}_{2}$ and $\mathrm{X}_{3}$ simultaneously on the $\mathrm{Y}$ variable. The magnitude of the coefficient of determination ranges from $0-1$. If the value of $\mathrm{R}$ square is getting smaller, the effect of the variable is also smaller. $\mathrm{X}$ on the $\mathrm{Y}$ variable, on the other hand, if the value of $\mathrm{R}$ square is greater or closer to 1 , the influence of the $\mathrm{X}$ variable will be stronger on the $\mathrm{Y}$ variable.

Table 7. Determination coefficient table

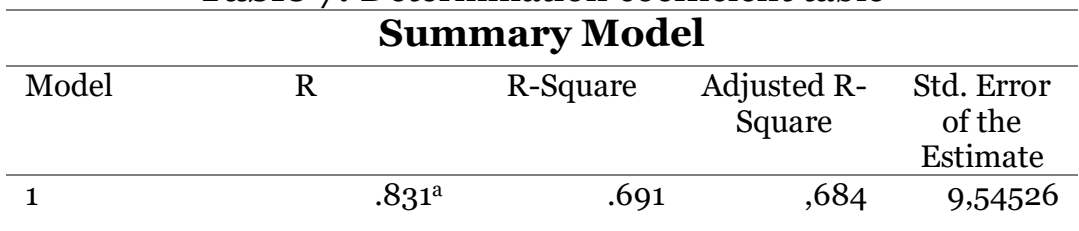

In this study, the results of the R square test were 0.691. The value of R Square of 0.691 is obtained from squaring the correlation coefficient $(\mathrm{R})$ value, which is $0.831 \times 0.831=0.691$. The magnitude of $\mathrm{R}$ square 0.691 is equal to $69.1 \%$, meaning that the influence of principal's academic supervision, principal's transformational leadership and school organizational climate on teacher pedagogic and professional competence is $69.1 \%$. The remaining $30.9 \%$ is influenced by other variables outside of this research variable.

\section{Dominant Factor}

The dominant factor to see the Effective Contribution (SE) and Relative Contribution (SR) aims to determine how much influence the independent variable has on the dependent variable. The formula for calculating SE is SE(X)\% = Beta X x Correlation Coefficient $\mathrm{x} 100 \%$ while the formula for calculating $\mathrm{SR}$ is $\mathrm{SR}(\mathrm{X}) \%=\mathrm{SE}(\mathrm{X}) \%$ / $\mathrm{R}$ Square. The data processing results show the magnitude of the weight of the effective contribution and the relative contribution for each independent variable shown in the following table.

Table 8. Effective Contribution and Relative Contribution

\begin{tabular}{lll}
\hline Principle Academic Supervision & SE & SR \\
\hline Principle Transformational Leadership & $36,53 \%$ & $53 \%$ \\
\hline School Climate & $20,62 \%$ & $40 \%$ \\
\hline Principle Academic Supervision & $11,90 \%$ & $17 \%$ \\
\hline Total & $69,1 \%$ & $100 \%$ \\
\hline
\end{tabular}

Source: Primary Data of 2021

The table above shows that the total Effective Contribution (SE) of the three independent variables of the study is $69.1 \%$. In detail, the SE of the principal's academic supervision variable is $36.53 \%$, the principal's transformational leadership variable is $20.62 \%$, and the school organizational climate variable is $11.90 \%$. While the Relative Contribution (SR) for the school principal's academic supervision variable is $53 \%$, the principal's transformational leadership variable is $30 \%$, and the school organizational climate variable is $17 \%$. From SE and SR, each independent variable can be concluded that the school principal's academic supervision variable has a very large influence on teachers' pedagogic competence and professional competence in senior high schools in Lembata Regency - East Nusa Tenggara. 


\section{Longginus Laga Belan, M.D Niron}

\section{Principle Academic Supervision (X1) toward Teacher Competency (Y)}

From the research conducted by the researchers, the following results were obtained. The majority in the moderate category of $66 \%$ is under the academic supervision of the principal at high school in Lembata. Meanwhile, teachers' pedagogical and professional competencies in the national exam subjects at senior high schools in Lembata Regency are in the medium category by $68 \%$. There is a significant effect of the principal's academic supervision on the pedagogical and professional competence of teachers of national examination subjects at senior high schools in Lembata, as evidenced by the t-count value of 3.937, the significance value of $0.000<0.05$ and the regression coefficient of 0.135. The pedagogic and professional competence of teachers is influenced by the academic supervision of the principal. It is also supported by the research of (Niswah, 2020) that states that there is an effect between professional and pedagogic competency of teachers toward principle academic supervision.

In the implication, the more the frequency of the principal's academic supervision in the form of providing professional assistance by offering solutions to the learning problems experienced by the teacher, the more the pedagogic and professional competence of the teacher will increase. Academic supervision carried out by the principal on an ongoing basis will foster teacher motivation to develop competence, leading to professionalism in carrying out tasks.

\section{Principle Transformational Leadership (X2) toward Teacher Competency (Y)}

The research results show that the transformational leadership of principals in senior high schools in Lembata is mostly in the moderate category by $64 \%$. There is a significant effect of the principal's transformational leadership on teachers' pedagogical and professional competence of national examination subjects at senior high schools in Lembata Regency as evidenced by the t-count value of 3.524 , the significance value of $0.001<0.05$ and the regression coefficient of 0.116 .123 . The results show that the principal's transformational leadership affects the pedagogic and professional competence of teachers. These results are in accordance with research (Narung, 2020) which states that the principal's transformational leadership affects teachers' pedagogic and professional competencies. However, this study rejects the results of research from Elvita, Sumarno, \& Rusdi, (2019), which states that the principal's transformational leadership does not influence the pedagogic and professional competence of teachers.

In the implementation, the principal transformational leadership must provide a positive change. In carrying out transformational leadership, the principal has a vision and rhetorical expertise that encourages teachers to continue developing their skills and competencies effectively and efficiently. The higher the communication and commitment built within the framework of transformational leadership, the higher teachers' pedagogic and professional competence in carrying out their duties.

\section{School Organizational Climate (X3) toward Teacher Competency (Y)}

Meanwhile, the school climate in senior high schools in Lembata is mostly in the moderate category by $64 \%$. There is a significant effect of the principal's academic supervision, principal's transformational leadership, and school climate together on the pedagogic and professional competence of teachers of national exam subjects at senior high schools in Lembata, as evidenced by the calculated $\mathrm{F}$ value of 91.810 . The significance value is $0.000<0,05$. The results show that the school climate affects the pedagogic and professional competence of teachers. The result of this study is not in accordance with research conducted by Nuraini (2016), which explains that there is no relationship between school climate and teacher pedagogic and professional competence.

It implies that feeling comfortable working in a conducive school climate will increase the teacher's competence. The school climate component consisting of the leadership and management of the principal and the way of interaction between all the academic communities can help improve the skills and competences of teachers. 


\section{Principal Academic Supervision, Principal Transformational Leadership, and School Organizational Climate Simultaneously toward Teacher Competence}

The results above show that the principal's academic supervision, transformational leadership, and school climate together have a significant influence on the pedagogic competence and professional competence of high school teachers in Lembata Regency. This is explained from the results of the $\mathrm{F}$ analysis, namely the F-count of 91,810 with a significance level of 0.000 . Because the significance value is smaller than $0.05(0.000<0.05)$, the fourth hypothesis says that there is an effect of the principal's academic supervision, the principal's transformational leadership and the school climate together on the pedagogic and professional competence of teachers in senior high schools in Indonesia. Lembata Regency, therefore the hypothesis is accepted. The results of this study are by the research of Ningsih, Herawan, \& Sutarsih (2016) which states that there is a relationship between the principal's academic supervision, the principal's transformational leadership and the school's climate together on the pedagogic and professional competence of teachers.

\section{CONCLUSION}

Academic supervision by the principal has a significant effect on teachers' pedagogical and professional competence in subjects covered by national examinations at senior high schools in Lembata, as evidenced by the t-count value of 3.937, the significance value of 0.0000.05, and the regression coefficient of 0.135 . As evidenced by the t-count value of 3.524, the significance value of 0.0010.05, and the regression coefficient of 0.116.123, the principal's transformational leadership has a significant effect on teachers' pedagogical and professional competence in national examination subjects at senior high schools in Lembata. The principal's academic supervision, the principal's transformational leadership, and the school climate all have a significant effect on the pedagogic and professional competence of teachers of national exam subjects at senior high schools in Lembata, as demonstrated by the calculated $\mathrm{F}$ value of 91.810 and the significance value of $0.0000,05$. The findings above indicate that academic supervision, transformational leadership, and school climate have a significant impact on the pedagogic and professional competence of Lembata high school teachers.

\section{REFERENCE}

Abidin, A. . (2019). Penerapan Pendidikan Karakter Pada Kegiatan Ekstrakurikuler Melalui Metode Pembiasaan. DIDAKTIKA : Jurnal Kependidikan. https://doi.org/10.30863/didaktika.v12i2.185

Aditomo, A., \& Faridz, N. F. (2019). Ketimpangan Mutu dan Akses Pendidikan di Indonesia: Potret Berdasarkan Survei PISA 2015. https://doi.org/10.31227/OSF.IO/K76G3

Ahyanuardi, A., Hambali, H., \& Krismadinata, K. (2018). Pengaruh Kompetensi Pedagogik Dan Profesional Guru Sekolah Menengah Kejuruan Pasca Sertfikasi Terhadap Komitmen Guru Melaksanakan Proses Pembelajaran. INVOTEK: Jurnal Inovasi Vokasional Dan Teknologi. https://doi.org/10.24036/invotek.v18i1.169

Alexander, C., Fox, J., \& Gutierrez, A. (2019). Conceptualising Teacher Professionalism. In Professionalism and Teacher Education. https://doi.org/10.1007/978-981-13-7002-1_1

Altun, B., \& Yengin Sarkaya, P. (2020). The actors of teacher supervision. Journal of Human Sciences. https://doi.org/10.14687/jhs.v17i1.5880

Anderson, M. (2017a). Transformational Leadership in Education: A Review of Existing Literature. International Social Science Review.

Anderson, M. (2017b). Transformational Leadership in Education: A Review of Existing Literature. 
Longginus Laga Belan , M.D Niron International Social Science Review, 93(1).

Andriani, S., Kesumawati, N., \& Kristiawan, M. (2018). The influence of the transformational leadership and work motivation on teachers performance. International Journal of Scientific and Technology Research.

Argina, A. W., Mitra, D., Ijabah, N., \& Setiawan, R. (2017). Indonesian Pisa Result: What Factors And What Should Be Fixed? Proceedings Education and Language International Conference, 1(1). http://lppm-unissula.com/jurnal.unissula.ac.id/index.php/ELIC/article/view/1212

Balyer, A. (2012). Transformational Leadership Behaviors of School Principals: A Qualitative Research Based on Teachers' Perceptions. International Online Journal of Educational Sciences.

Bardach, L., \& Klassen, R. M. (2020). Smart teachers, successful students? A systematic review of the literature on teachers' cognitive abilities and teacher effectiveness. In Educational Research Review. https://doi.org/10.1016/j.edurev.2020.100312

Bass, B. M. (1995). Theory of Transformational Leadership Redux. Leadership Quarterly, 6(4).

Capp, G., Astor, R. A., \& Gilreath, T. D. (2020). Advancing a Conceptual and Empirical Model of School Climate for School Staff in California. Journal of School Violence. https://doi.org/10.1080/15388220.2018.1532298

Copeland, M. K. (2014). The Emerging Significance of Values-Based Leadership: A Literature Review. International Journal of Leadership Studies.

Damayanti, D. (2017). Kemampuan Manajerial Kepala Sekolah, Iklim Sekolah Dan Mutu Sekolah Dasar. Jurnal Administrasi Pendidikan UPI. https://doi.org/10.17509/jap.v24i1.6525

David, F. R. (2011). Strategic Management: Concepts and Cases (Thirteenth Edition). In Prentice Hall (Vol. 13).

Day, C., Gu, Q., \& Sammons, P. (2016). The Impact of Leadership on Student Outcomes: How Successful School Leaders Use Transformational and Instructional Strategies to Make a Difference. Educational Administration Quarterly. https://doi.org/10.1177/0013161X15616863

Del Zulia Venezuela, U., Parji, F. ;, \& Prasetya, A. (2020). Community Participation in Developing Educational Quality for Primary School in Madiun City. 25. https://doi.org/10.5281/zenodo.3987601

Dewi, M. P., Rahmatunnisa, M., Sumaryana, A., \& Kristiadi, J. B. (2018). Ensuring service quality in education for Indonesia's sustainable education. Journal of Social Studies Education Research. https://doi.org/10.17499/jsser.26856

Elvita, J., Sumarno, S., \& Rusdi, R. (2019). Pengaruh Kepemimpinan Transformasional Kepala Sekolah, Kompetensi Pedagogik, Dan Motivasi Kerja Guru Terhadap Mutu Pendidikan Pada Sekolah Dasar Negeri Di Kota Pekanbaru. Jurnal JUMPED (Jurnal Manajemen Pendidikan). https://doi.org/10.31258/jmp.7.1.p.54-67

Fitriatun, E. (2020). Kebijakan Merdeka Belajar Sebagai Strategi Peningkatan. Tawadhu.

Glickman, C. D., Gordon, S. P., \& Ross-Gordon, J. M. (2017). SuperVision and Instructional Leadership: A Developmental Approach [8th Edition] pdf. In $S$.

Grochalska, M. (2020). Not teaching, but coaching creating a self-development culture in a classroom. Journal of Education Culture and Society. https://doi.org/10.15503/jecs20132.273.287

Hakim, A. (2015). Contribution of Competence Teacher (Pedagogical, Personality, Professional Competence and Social) On the Performance of Learning. The International Journal Of 
Engineering And Science.

Hardono, Haryono, A. Y. (2017). Kepemimpinan Kepala Sekolah, Supervisi Akademik, dan Motivasi Kerja dalam Meningkatkan Kinerja Guru. In Jurnal unnes.

Hill, H., \& Wie, T. K. (2012). Indonesian universities in transition: Catching up and opening up. Bulletin of Indonesian Economic Studies. https://doi.org/10.1080/00074918.2012.694156

Hong, J. S., Espelage, D. L., \& Lee, J. M. (2018). School Climate and Bullying Prevention Programs. In The Wiley Handbook on Violence in Education. https://doi.org/10.1002/9781118966709.ch17

Hsiao, H. C., \& Chang, J. C. (2011). The role of organizational learning in transformational leadership and organizational innovation. Asia Pacific Education Review. https://doi.org/10.1007/s12564011-9165-x

Judiani, S. (2011). Kreativitas Dan Kompetensi Guru Sekolah Dasar. Jurnal Pendidikan Dan Kebudayaan, 17(1). https://doi.org/10.24832/jpnk.v17i1.7

Kholis, N. (2019). Teacher Professionalism in Indonesia, Malaysia, and New Zealand. TARBIYA: Journal of Education in Muslim Society. https://doi.org/10.15408/tjems.v6i2.11487

Khun-Inkeeree, H., Dali, P. D., Daud, Y., Fauzee, M. S. O., \& Khalid, R. (2019). Effects of teaching and learning supervision on teachers attitudes to supervision at secondary school in Kubang Pasu District, Kedah. International Journal of Instruction. https://doi.org/10.29333/iji.2019.12185a

King, F. (2014). Evaluating the impact of teacher professional development: an evidence-based framework. Professional Development in Education. https://doi.org/10.1080/19415257.2013.823099

Kraft, M. A. (2019). Teacher effects on complex cognitive skills and social-emotional competencies. Journal of Human Resources. https://doi.org/10.3368/JHR.54.1.0916.8265R3

Latifah, M., \& Amelia, R. (2019). Predictors of Adolescent Academic Achievement: The Role of Individual and Family Socioeconomic Factors. Journal of Family Sciences, 4(2), 105-119. https://doi.org/10.29244/JFS.4.2.105-119

Li, L., \& Liu, Y. (2020). An integrated model of principal transformational leadership and teacher leadership that is related to teacher self-efficacy and student academic performance. Asia Pacific Journal of Education. https://doi.org/10.1080/02188791.2020.1806036

Maba, W. (2018). Conducting assessment instrument models for teacher competence, teacher welfare as an effort to enhance education quality. International Research Journal of Management, IT and Social Sciences. https://doi.org/10.21744/irjmis.v5i3.667

Magill, M. S., Yost, P. R., Chighizola, B., \& Stark, A. (2020). Organizational climate for climate sustainability. Consulting Psychology Journal. https://doi.org/10.1037/cpb0000163

Maritasari, D. B., Setyosari, P., Kuswandi, D., \& Praherdhiono, H. (2020). The effect of training and supervision on teacher performance through teacher competence as a mediating variable in primary schools. Universal Journal of Educational Research. https://doi.org/10.13189/ujer.2020.082312

Maryanti, N., Rohana, R., \& Kristiawan, M. (2020). The Principal's Strategy In Preparing Students Ready To Face The Industrial Revolution 4.0. INTERNATIONAL JOURNAL OF EDUCATIONAL REVIEW. https://doi.org/10.33369/ijer.v2i1.10628

Mette, I., Aguilar, I., \& Wieczorek, D. (2020). A Thirty State Analysis of Teacher Supervision and Evaluation Systems in the ESSA Era. Journal of Educational Supervision. https://doi.org/10.31045/jes.3.2.7 
Academic Supervision of School Principals, Principal Transformational Leadership, and School Climate on Senior High School Teachers'

Competence, Al- Ishlah: Jurnal Pendidikan, 2021, vol.13 (3), Pages 2132-2145

Longginus Laga Belan, M.D Niron

Mkumbo, K. A. K., \& Amani, J. (2012). Perceived University Students' Attributions of Their Academic Success and Failure. Asian Social Science. https://doi.org/10.5539/ass.v8n7p247

Mohzan, M. A. M., Hassan, N., \& Halil, N. A. (2013). The Influence of Emotional Intelligence on Academic Achievement. Procedia - Social and Behavioral Sciences. https://doi.org/10.1016/j.sbspro.2013.07.095

Mora, C. (2012). Transformational Leadership in Education: Concept Analysis. Transylvanian Review of Administrative Sciences, Special Issue, 184-192.

Nag, S., Chiat, S., Torgerson, C., \& Snowling, M. J. (2014). Literacy, Foundation Learning and Assessment in Developing Countries: Final Report. Education Rigorous Literature Review. http://r4d.dfid.gov.uk/andtheEPPI-Centrewebsite:http://eppi.ioe.ac.uk/

Narung, R. M. (2020). Kontribusi Kepemimpinan Transformasional Kepala Sekolah, Etos Kerja Guru, dan Kompetensi Pedagogik Terhadap Kinerja Guru. Media Manajemen Pendidikan. https://doi.org/10.30738/mmp.v2i3.6783

Ningsih, R., Herawan, E., \& Sutarsih, C. (2016). Kinerja Manajerial Kepala Sekolah, Iklim Sekolah Dan Mutu Sekolah Dasar. Jurnal Administrasi Pendidikan Indonesia. https://doi.org/10.17509/jap.v23i2.5642

Niswah, W. (2020). Analisis Supervisi Akademik Kepala Sekolah dan Budaya Sekolah Terhadap Kompetensi Pedagogik Guru SD di Kabupaten Demak. JPAI: Jurnal Perempuan Dan Anak Indonesia. https://doi.org/10.35801/jpai.2.1.2020.31181

Nuraini, M. (2016). Pengaruh Supervisi Akademik Dan Iklim Sekolah Terhadap Kompetensi Pedagogik Guru Pai SD Di Kota Bengkulu. Al Bahtsu.

Oktiningrum, W., Zulkardi, Z., \& Hartono, Y. (2016). Developing Pisa-Like Mathematics Task With Indonesia Natural And Cultural Heritage As Context To Assess Students Mathematical Literacy. Journal on Mathematics Education, 7(1), 1-8. https://doi.org/10.22342/JME.7.1.2812.1-8

Orchard, J., \& Winch, C. (2015). What training do teachers need?: Why theory is necessary to good teaching. Impact. https://doi.org/10.1111/2048-416x.2015.12002.x

Pangestu, K., \& Nuraini, N. L. . (2020). Kesiapan Calon Guru Sekolah Dasar Dalam Menghadapi Era Revolusi Industri. ELEMENTARY SCHOOL JOURNAL PGSD FIP UNIMED, 10(2), 40-47.

Poernamawijaya, L. W., Sulaiman, Suriansyah, A., \& Dalle, J. (2018). Contribution On Supervision Of Supervisor, Principals Motivation, Kindergarten Teacher Performance To Improving The Kindergarten Quality In West Banjarmasin, Indonesia. European Journal of Alternative Education Studies.

Renata, Wardiah, D., \& Kristiawan, M. (2018). The influence of headmaster's supervision and achievement motivation on effective teachers. International Journal of Scientific and Technology Research.

Rofiq, C. (2019). Kepemimpinan Transformasional Dalam Lembaga Pendidikan Madrasah. Jurnal Penelitian Agama. https://doi.org/10.24090/jpa.v20i2.2019.pp203-226

Ronfeldt, M., Farmer, S. O., McQueen, K., \& Grissom, J. A. (2015). Teacher Collaboration in Instructional Teams and Student Achievement. American Educational Research Journal. https://doi.org/10.3102/0002831215585562

Rosser, A. (2018). Beyond access: Making Indonesia's education system work. Lowy Institute For International Policy.

Rudasill, K. M., Snyder, K. E., Levinson, H., \& L. Adelson, J. (2018). Systems View of School Climate: 
a Theoretical Framework for Research. In Educational Psychology Review. https://doi.org/10.1007/s10648-017-9401-y

Sachs, J. (2016). Teacher professionalism: Why are we still talking about it? Teachers and Teaching: Theory and Practice. https://doi.org/10.1080/13540602.2015.1082732

Şahin, F., Gürbüz, S., \& Şeşen, H. (2017). Leaders' managerial assumptions and transformational leadership: the moderating role of gender. Leadership \& Organization Development Journal, 38(1).

Sebastian, J., \& Allensworth, E. (2012). The Influence of Principal Leadership on Classroom Instruction and Student Learning: A Study of Mediated Pathways to Learning. Educational Administration Quarterly. https://doi.org/10.1177/0013161X11436273

Selvi, K. (2010). Teachers' competencies. In Cultura. International Journal of Philosophy of Culture and Axiology. https://doi.org/10.5840/cultura20107133

Sileo, J. M. (2011). Co-Teaching: Getting to Know Your Partner. TEACHING Exceptional Children. https://doi.org/10.1177/004005991104300503

Supriyono, S., Ali Imron, A., Imron Arifin, I., \& Kusmintardjo, K. (2017). The Situational Behavior Orientation of Instructional Supervision: A Multisite Study. https://doi.org/10.2991/coema17.2017.52

Susanti, S., Wardiah, D., \& Lian, B. (2020). Effect of Academic Supervision of School Heads and School Culture on Quality Teaching Teachers. International Journal of Progressive Sciences and Technologies, 20(1), 67-77.

Thapa, A., Cohen, J., Guffey, S., \& Higgins-D’Alessandro, A. (2013). A Review of School Climate Research. In Review of Educational Research. https://doi.org/10.3102/0034654313483907

VanLone, J., Freeman, J., LaSalle, T., Gordon, L., Polk, T., \& Rocha Neves, J. (2019). A Practical Guide to Improving School Climate in High Schools. Intervention in School and Clinic. https://doi.org/10.1177/1053451219832988

Wagner, I. (2020). Effectiveness and perceived usefulness of follow-up classroom observations after school inspections in Northern Germany. Studies in Educational Evaluation. https://doi.org/10.1016/j.stueduc.2020.100913 